\title{
Purinergic Receptors and Their Activation by Endogenous Purines at Perisynaptic Glial Cells of the Frog Neuromuscular Junction
}

\author{
Richard Robitaille \\ Centre de Recherche en Sciences Neurologiques and Département de Physiologie, Université de Montréal, \\ Montréal, Canada $\mathrm{H} 3 \mathrm{C}$ 3J7
}

\begin{abstract}
Glial cells are closely associated with synapses and are modulated by neurotransmitters released during synaptic transmission. At many synapses, ATP is released during synaptic transmission and is involved in cell-cell signaling. Since glial cells have purinoceptors, it is possible that ATP mediates synaptic neuron-glia signaling. This work aims at determining which types of purinoceptors are present on perisynaptic Schwann cells, the perisynaptic glial cells at the frog neuromuscular junction, and test their sensitivity to endogenous purines by monitoring the relative changes of intracellular $\mathrm{Ca}^{2+}$. Local application of ATP induced the release of $\mathrm{Ca}^{2+}$ from internal stores. Adenosine induced $\mathrm{Ca}^{2+}$ responses that were blocked by $\mathrm{A1}$ receptor antagonists and mimicked by an $A 1$ receptor agonist and were caused by the release of $\mathrm{Ca}^{2+}$ from internal stores via a pertussis toxin-sensitive G-protein. A2 receptor antagonists had no effect on $\mathrm{Ca}^{2+}$ responses induced by adenosine. Me-S-ATP, an ATP analog, triggered $\mathrm{Ca}^{2+}$ release from internal stores via a pertussis toxin-sensitive G-protein, consistent with the activation of $P_{2 Y}$ receptors. L-AMP-PCP, another ATP analog, induced $\mathrm{Ca}^{2+}$ entry mainly through L-type $\mathrm{Ca}^{2+}$ channels by a pertussis toxin-insensitive mechanism, consistent with the activation of $P_{2 x}$ receptors. Blockade of adenosine receptors did not affect glial $\mathrm{Ca}^{2+}$ responses induced by nerve evoked transmitter release. However, blockade of ATP receptors reduced the size and increased the delay of the responses. Hence, purinoceptors are present on the perisynaptic Schwann cells and are activated by endogenous ATP released during synaptic transmission.
\end{abstract}

[Key words: adenosine, ATP, $\mathrm{Ca}^{2+}, \mathrm{Ca}^{2+}$ channels, purinoceptor, Schwann cell, glial cell, transmitter release, synapse, neuromuscular junction]

Glial cells are active components of the nervous system, possess numerous types of receptors for different neurotransmitters as well as a large variety of ion channels (Hamprecht, 1986; Barres

Received Apr. 3. 1995; revised July 14, 1995; accepted July 25, 1995.

I thank Milton P. Charlton, John Georgiou, and Rémy Sauvé for helpful suggestions and critical reading of the manuscript and Daniel Cyr for his help in the preparation of the figures. This work was supported by a grant from the Medical Research Council of Canada (MT-12057), Fonds de la Recherche en Santé du Québec (930093-103), a team grant from FCAR (95ER2119), and grants from Université de Montréal (CAFIR and FDR). R.R. was a scholar of the Medical Research Council of Canada and an Alfred P. Sloan Research Fellow.

Correspondence should be adressed to Richard Robitaille, Département de Physiologie, Iniversité de Montréal, P.O. Box 6128, Station "Centre-Ville," Montréal, Canada H3C $3 \mathrm{~J} 7$

Copyright $(1995$ Society for Neuroscience $0270-6474 / 95 / 157121-11 \$ 05.00 / 0$ et al., 1990). Equipped with this cellular machinery, glial cells closely associated with synapses react to the release of neurotransmitters during synaptic transmission (Chiu and Kriegler, 1994). Synaptic activity generates $\mathrm{Ca}^{2+}$ responses in a network of astrocytes in the hippocampus (Dani et al., 1992) and the release of neurotransmitters by a single synapse at the frog neuromuscular junction is sufficient to induce $\mathrm{Ca}^{2+}$ responses in perisynaptic glial cells (Jahromi et al., 1992; Reist and Smith, 1992). These responses are mimicked by local applications of neurotransmitters present in synaptic vesicles (Jahromi et al., 1992, 1993).

In addition to $\mathrm{ACh}$, a large concentration of ATP is also released during synaptic transmission (Smith, 1991; Zimmermann, 1994). More than playing its ubiquitous role in energy supply, ATP has been proposed to be involved in intercellular signaling in various systems of the peripheral and central nervous systems (Sneddon et al., 1982; Sneddon and Burnstock, 1984; Lindgren and Smith, 1987; Benham, 1989; El-Moatassim et al., 1992; Evans et al., 1992; Salter and Hicks, 1994; Zimmermann, 1994; Lyons et al., 1995). Among other mechanisms, ATP has been shown to increase intracellular $\mathrm{Ca}^{2}$ (O'Connor et al., 1991) ejther by releasing $\mathrm{Ca}^{2+}$ from internal stores or by regulating $\mathrm{Ca}^{2+}$ entry. At the frog $\mathrm{nmj}$, application of ATP on perisynaptic Schwann cells (PSC) induces the release of $\mathrm{Ca}^{2+}$ from internal stores (Jahromi et al., 1992). The goal of this work was to characterize further the mechanisms responsible for the $\mathrm{Ca}^{2+}$ responses evoked by ATP in PSCs of the frog $n m j$ and examine the involvement of endogenous purines in the modulation of synaptic glial cells in situ.

There are two classes of purinoceptors based upon their selectivity to adenosine ( $\mathrm{P} 1$ receptors) and ATP ( $\mathrm{P} 2$ receptors). Adenosine receptors are divided into two main groups, $\mathrm{Al}$ and A2 receptors, based on their ability to respectively inhibit or facilitate adenylate cyclase and also on their respective structureactivity and interactions with various drugs (Linden, 1991). ATP receptors are divided in five groups. The $\mathrm{P}_{2 X}, \mathrm{P}_{2 \mathrm{~T}}$, and $\mathrm{P}_{2 Z}$ receptors are permeable to various ions including $\mathrm{Ca}^{2+}$, whereas $\mathrm{P}_{2 Y}$ and $\mathrm{P}_{2 U}$ receptors mediate the release of $\mathrm{Ca}^{2+}$ from internal stores via G-binding proteins (G-protein) (Burnstock, 1990; O'Connor et al., 1991; Barnard et al,, 1994). Additional characterization has been achieved at the molecular level where three different genes for $\mathrm{P}_{2 Y}$ receptors were cloned showing a strong homology to $G$ protein-coupled receptors (Barnard et al., 1994), two $P_{2 X}$ receptors have been cloned showing homologies with the transmitter-gated ion channel superfamily (Barnard, 1992) and many adenosine receptors have been also identified at the molecular level (Müller and Scior, 1993). 
Table 1. Purinoceptors and their regulatory mechanisms at PSCs of the frog $\mathrm{nm}$

\begin{tabular}{|c|c|c|c|c|c|c|c|c|c|}
\hline & & $\begin{array}{l}\text { Normal } \\
\text { Ringer }\end{array}$ & $\begin{array}{l}0 \mathrm{Ca}^{2+} \\
5 \mathrm{Mg}^{2+}\end{array}$ & $\mathrm{Cd}^{2+}$ & $\begin{array}{l}(+) R- \\
\text { Bay K } \\
8644\end{array}$ & Suramin & DPCPX & $\mathrm{CPT}$ & PTX \\
\hline \multirow[t]{3}{*}{$\mathrm{P} 2$} & ATP & $\begin{array}{r}262 \\
\pm 48\end{array}$ & NA & NA & NA & NA & NA & NA & NA \\
\hline & L-AMP-PCP & $\begin{array}{r}121 \\
\pm 14\end{array}$ & $\begin{array}{r}25 \\
+9\end{array}$ & $\begin{array}{r}12 \\
+8\end{array}$ & $\begin{array}{r}25 \\
\pm 12\end{array}$ & $\begin{array}{r}10 \\
\pm 4\end{array}$ & $\begin{array}{r}115 \\
\pm 14\end{array}$ & NA & $\begin{array}{r}126 \\
\pm 24\end{array}$ \\
\hline & MeSATP & $\begin{array}{r}212 \\
\pm 29\end{array}$ & $\begin{array}{r}184 \\
\pm 27\end{array}$ & NA & NA & $\begin{array}{r}19 \\
\pm 6\end{array}$ & $\begin{array}{r}203 \\
\pm 25\end{array}$ & NA & $\begin{array}{r}29 \\
\pm 6\end{array}$ \\
\hline \multirow[t]{2}{*}{ P1 } & Adenosine & $\begin{array}{r}229 \\
\pm 42\end{array}$ & $\begin{array}{r}159 \\
\pm 26\end{array}$ & $\mathrm{NA}$ & NA & $\begin{array}{r}215 \\
\pm 20\end{array}$ & $\begin{array}{r}4 \\
\pm 1\end{array}$ & $\begin{array}{r}51 \\
\pm 18\end{array}$ & $\begin{array}{r}23 \\
\pm 9\end{array}$ \\
\hline & CPA & $\begin{array}{r}205 \\
\pm 22\end{array}$ & $\mathrm{NA}$ & NA & NA & $\mathrm{NA}$ & NA & $\mathrm{NA}$ & $\mathrm{NA}$ \\
\hline $\begin{array}{c}\text { Nerve } \\
\text { stim. }\end{array}$ & $50 \mathrm{~Hz}, 30 \mathrm{sec}$ & $\begin{array}{r}326 \\
\pm 59\end{array}$ & NA & NA & NA & $\begin{array}{r}87 \\
+45\end{array}$ & $\begin{array}{r}396 \\
+69\end{array}$ & NA & NA \\
\hline
\end{tabular}

Values are the mean \pm SEM of the relative changes of fluorescence $(\Delta F / F)$ obtained following local applications of agonists in various experimental conditions. Data are grouped according to the agonist specificity for PI or P2 receptors. Data from nerve-evoked $\mathrm{Ca}^{2+}$ responses are also presented (Nerve stim.). NA, data not available.

We report here that PSCs at the frog nmj posses ATP and adenosine receptors. ATP but not adenosine receptors regulate nerve-evoked $\mathrm{Ca}^{2+}$ responses in PSCs.

Preliminary results have appeared (Robitaille, 1994).

\section{Materials and Methods}

Experiments were performed on nmjs of cutaneous pectoris muscles of Rana pipiens frogs. Unless stated otherwise, the physiological solution contained (in mM): $120 \mathrm{NaCl}, 2 \mathrm{KCl}, 1 \mathrm{NaHCO}_{3}, 1.8 \mathrm{CaCl}_{2}, 5$ HEPES. The $\mathrm{pH}$ was adjusted at 7.2 .

Calcium imaging of PSCs. Nerve-muscle preparations were isolated from the frogs and pinned down in a recording chamber coated with Sylgard. The membrane permeant form of the $\mathrm{Ca}^{2+}$ indicator fluo 3 (fluo 3-AM, Molecular Probes) was used. The fluorescence emitted by fluo 3 increases when it is bound to $\mathrm{Ca}^{2+}$ (Kao et al., 1989). For loading the $\mathrm{Ca}^{2+}$ indicator into the PSCs, preparations were incubated for $120-$ $150 \mathrm{~min}$ at $21-23^{\circ} \mathrm{C}$ with a solution containing $10 \mu \mathrm{M}$ fluo $3-\mathrm{AM}$ with a final concentration of $1 \%$ dimethyl sulfoxide and $0.02 \%$ pluronic acid. Heavy metal ions that limit the response of fluo 3 to $\mathrm{Ca}^{2+}$ were partially chelated using tetrakis (2-pyridylmethyl) ethylenediamine (TPEN, 20

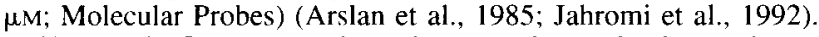

Changes in fluorescence intensity were detected using an intensified CCD camera system (Sony camera XC-77 and a Hamamatsu intensifier, C-2487) and images were digitized by a computer using the IMAGE 1 software (Universal Imaging). A $40 \times$ water immersion lens was used (Nikon, $0.55 \mathrm{NA}$ ) and an additional magnification was obtained with an optizoom (Nikon). The excitation wave length was $485 \pm 20 \mathrm{~nm}$ and emitted fluorescence was detected through a low pass filter with cutoff at $515 \mathrm{~nm}$. Surface nmjs were located using transmitted light microscopy and reliable identification of PSCs was based on their shape, size and association with the motor endplate (Georgiou et al., 1994b). Neutral density filters of at least $50 \%$ were used to minimize damage of the preparations with excess of light energy. With these precautions, PSCs at nmjs could be repeatedly observed with no signs of cell damage or bleaching of the fluorescence. The fluorescence intensity $(F)$ was measured over the PSCs cell body and the relative changes in fluorescence intensity were expressed as

$$
\Delta F / F=\left(F-F_{\text {rest }}\right) / F_{\text {rest }} \text {. }
$$

To reduce discrepancies in $\mathrm{Ca}^{2+}$ responses between different preparations, care was taken to use only cells that had resting fluorescence level which allowed the use of similar gain and digital offset parameters.

Drug applications. Agonists were applied locally on PSCs using micropipettes (tip diameter, 2-3 $\mu \mathrm{m}$ ). Agonist solutions were prepared with the same solution used for perfusion so that the only difference between the agonist solution and the perfusion solution was the presence of the agonist. The tip of the pipette was positioned close to the
PSCs soma under visual control at high magnification (40X objective) and the agonist solution was applied with a 1 sec pulse of positive pressure (5-10 psi) with a Picospritzer II (General Valve, Fairfield, NJ). For experiments where external $\mathrm{Ca}^{2+}$ ions were replaced by $5 \mathrm{~mm}$ $\mathrm{MgCl}_{2}$, preparations were incubated for 30 min with $0 \mathrm{Ca}^{2+}-5 \mathrm{Mg}^{2+}$ Ringer's before imaging. When ethylene glycol bis( $\beta$-aminoethylether)$N, N, N^{\prime}, N^{\prime}$-tetraacetic acid (EGTA) was added to the $0 \mathrm{Ca}^{2+}-5 \mathrm{~mm}$ $\mathrm{MgCl}_{2}$ solution, imaging was started $10-20 \mathrm{~min}$ after application of the EGTA solution.

Incubation with pertussis toxin. Nerve-muscle preparations were incubated for $12-16 \mathrm{hr}$ at $20-22^{\circ} \mathrm{C}$ in normal frog Ringer's containing 2 $\mu \mathrm{g} / \mathrm{ml}$ of pertussis toxin (PTX, RBI). The PTX solution was replaced with fresh toxin solution at least twice during the incubation period.

$\mathrm{Ca}^{2+}$ responses evoked by nerve stimulation. Nerve-muscle preparations were processed for fluo 3 loading as described above. Cholinergic receptors were blocked with $\alpha$-bungarotoxin ( $\alpha$-BuTx) $(10 \mu \mathrm{g} / \mathrm{ml} ; \mathrm{Mo}-$ lecular Probes) for $10 \mathrm{~min}$ to prevent muscle contractions evoked by transmitter release. $\alpha$-BuTx does not affect $\mathrm{Ca}^{2+}$ responses of the PSCs (Jahromi et al., 1992, 1993). Motor axons were stimulated at $50 \mathrm{~Hz}$ for $30 \mathrm{sec}$ and changes in intracellular $\mathrm{Ca}^{2+}$ were monitored as described above. Preparations were allowed to rest for $20 \mathrm{~min}$ between train of stimuli when several trains were performed on the same preparation.

Drug supplies. Drugs were obtained from Research Biochemical Inc. except for EGTA (Sigma) and suramin (RBI or Calbiochem).

Statistical analyses. Statistical comparisons were performed using an analysis of variance to avoid problems caused by repeated Student $t$ tests. Data were grouped around the control sample (agonist alone in normal $\mathrm{Ca}^{2+}$; normal Ringer's, Table 1) and compared to the changes in fluorescence obtained with the agonist alone. Thus, all experiments involving adenosine for example, were compared at once using an Analysis of variance with the values obtained with adenosine alone. A Student paired $t$ test was used when two treatments were performed on the same cell and a Student $t$ test was used for comparisons between different groups (for example adenosine vs ATP).

\section{Results}

\section{ATP induces the release of $\mathrm{Ca}^{2+}$ from internal stores}

To test whether ATP can activate PSCs, changes in intracellular $\mathrm{Ca}^{2+}$ induced by local application of ATP were monitored. Figure 1 shows the level of $\mathrm{Ca}^{2+}$ in four PSCs at rest $(\Lambda I)$, at the peak of the $\mathrm{Ca}^{2+}$ response elicited by $20 \mu \mathrm{M}$ ATP $(A 2)$ and after recovery (A3). Similar to our earlier report, ATP induced $\mathrm{Ca}^{2+}$ responses in PSCs $(\Delta F / F=262 \pm 48 \%$; two muscles, 15 cells $)$ (Table 1) even in absence of external $\mathrm{Ca}^{2+}$ (data not shown, see Jahromi et al., 1992). This indicates that ATP induces the release of $\mathrm{Ca}^{2+}$ from internal stores. 

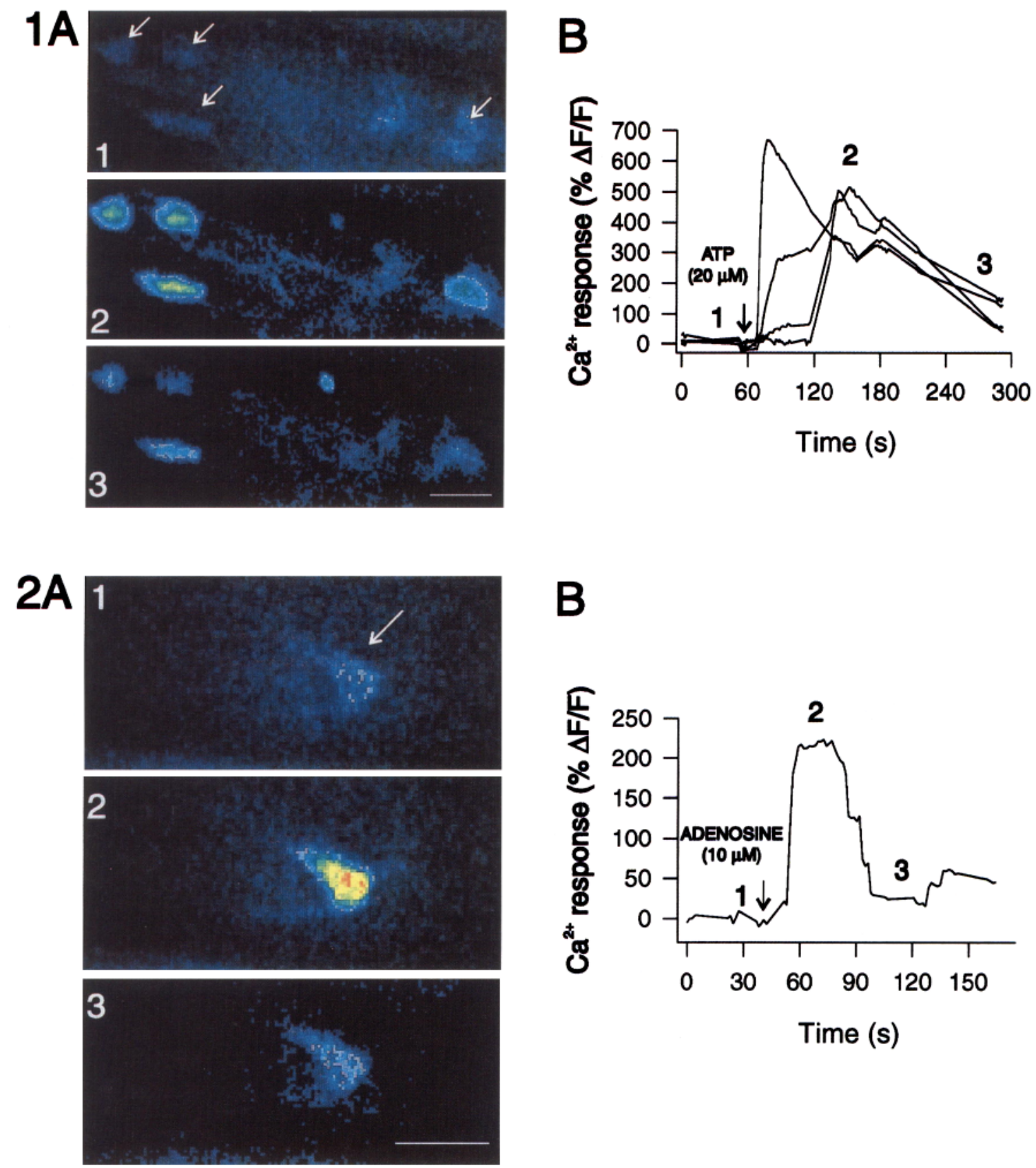

Figure 1. $\mathrm{Ca}^{2+}$ responses in PSCs elicited by a local application of ATP. A. False color images of four PSCs (arrows) where blue indicates a low level of $\mathrm{Ca}^{2+}$ and red a high level. Al shows the PSCs before local application of ATP $(20 \mu \mathrm{M}) ; A 2$ shows the cells shortly after application and $A 3$ after recovery following drug application. $B$, Changes of fluorescence $(\Delta F / F)$ of the same four PSCs shown in $A$, before and after application (arrow) of ATP $(20 \mu \mathrm{M})$. Each trace on the graph illustrates the time course of the $\mathrm{Ca}^{2+}$ response for each PSC, and the numbers indicate the respective time at which images in $A$ were taken. Scale bar, $20 \mu \mathrm{m}$.

Figure 2. $\mathrm{Ca}^{2+}$ response of PSCs to local application of adenosine. A, False color images of a PSC (arrow) before (1), shortly after local application of adenosine $(10 \mu \mathrm{M})(2)$, and after recovery following drug application (3). B, Changes of fluorescence of the same PSC shown in $A$, before and after application (arrow) of adenosine $(10 \mu \mathrm{M})$. Numbers on the graph indicate the respective time at which images in $A$ were taken. Scale bar, $20 \mu \mathrm{m}$.

However, ecto-enzymes present in the synaptic cleft (Lai and Wong, 1991; Salter et al., 1993; Ziganshin et al., 1993) will dephosphorylate ATP to form adenosine. Since adenosine is an active substance in many cells, and at the frog $\mathrm{nmj}$ in particular (Silinsky, 1975; White, 1988; Meriney and Grinnell, 1991; Salter et al., 1993), it is possible that the effects observed with ATP are due to the action of adenosine. To test for the presence of adenosine and ATP receptors, a series of experiments were per- formed to monitor the effects on $\mathrm{Ca}^{2+}$ responses of various agonists and antagonists of $\mathrm{P} 1$ and $\mathrm{P} 2$ receptors.

\section{Adenosine induces $\mathrm{Ca}^{2+}$ responses in PSCs}

When applied locally, adenosine $(10 \mu \mathrm{M})$ induced $\mathrm{Ca}^{2+}$ responses ( $229 \pm 42 \%$; four muscles, 22 cells) in all PSCs tested. Figure 2 shows the $\mathrm{Ca}^{2+}$ level in one PSC before $(A I)$, shortly after local application of adenosine (A2), and following recovery 

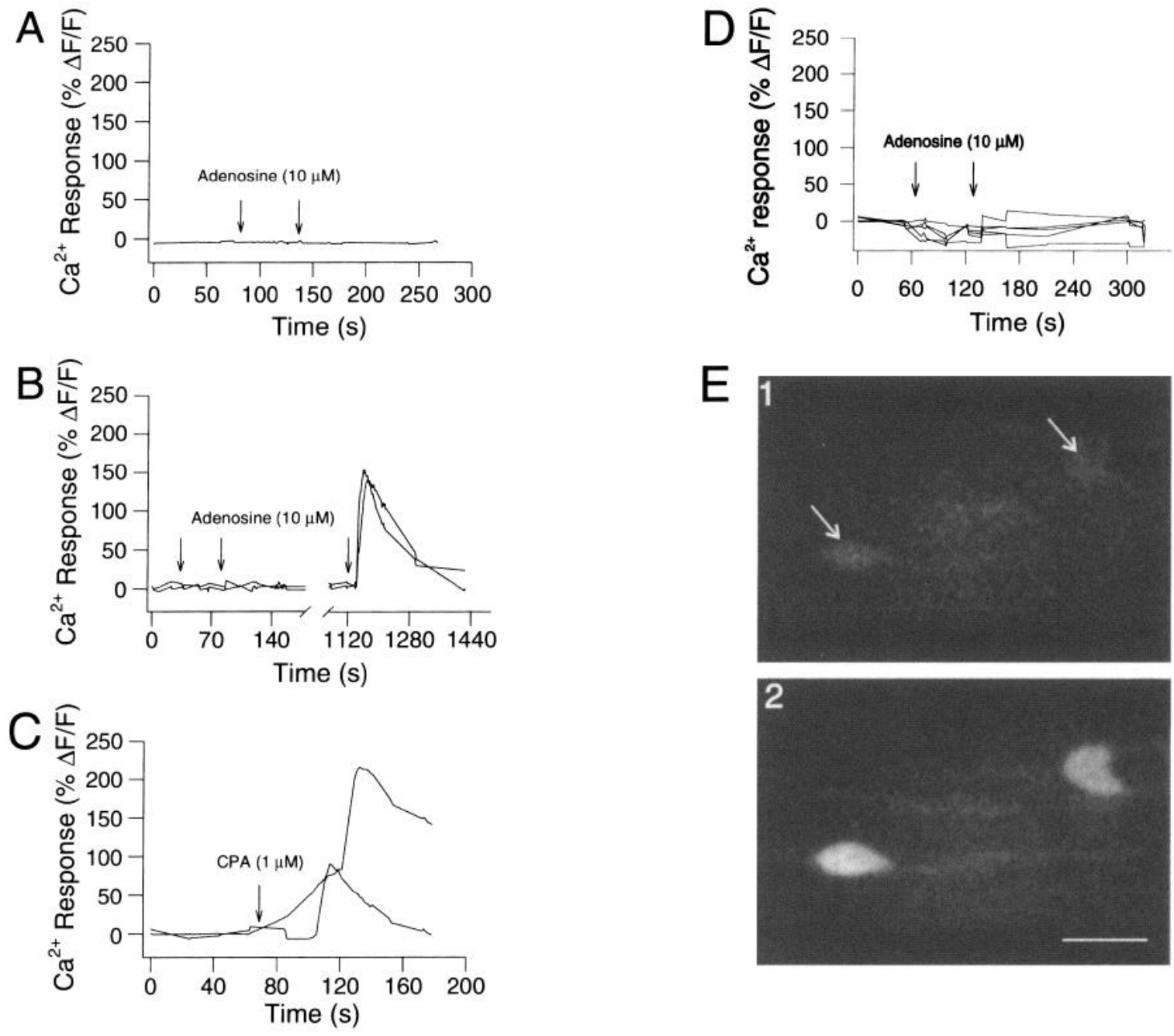

Figure 3. Al adenosine receptors release $\mathrm{Ca}^{2+}$ from internal stores via a G-protein. $A$, Changes of fluorescence of one PSC induced by applications of adenosine $(10 \mu \mathrm{M})($ arrows $)$ in presence of the A1 receptor antagonist DPCPX $(2 \mu \mathrm{M})$. Note the absence of Ca ${ }^{2+}$ responses. B, Changes of fluorescence of two PSCs before and after local applications (arrows) of adenosine (10 $\mu \mathrm{M})$ in presence of the Al antagonist CPT ( $2 \mu \mathrm{M})$. After washout of the antagonist (break in the x-axis), local application of adenosine (arrow) induced $\mathrm{Ca}^{2+}$ responses in the same two PSCs. $C$, Changes of fluorescence of two PSCs before and after application (arrow) of CPA (2 $\mu \mathrm{M})$, an A1 agonist. Each trace on the graphs illustrates the time course of the $\mathrm{Ca}^{2+}$ response for a PSC. D, Changes in fluorescence before and after local applications (arrows) of adenosine (10 $\left.\mu \mathrm{M}\right)$ on five PSCs incubated for $14 \mathrm{hr}$ with PTX $(2 \mu \mathrm{g} / \mathrm{ml})$. Each line on the graph illustrates the time course of the $\mathrm{Ca}^{2+}$ response for a PSC. Note the absence of $\mathrm{Ca}^{2+}$ responses in these conditions. E. Images of two PSCs (arrows) before (1) and after (2) local application of adenosine (10 $\left.\mu \mathrm{M}\right)$ following 30 min of perfusion with $0 \mathrm{Ca}^{2+}-5 \mathrm{Mg}^{2+}$ physiological solution. Note the increase in fluorescence intensity of the two PSCs indicating an increase in intracellular $\mathrm{Ca}^{2+}$. Scale bar, $20 \mu \mathrm{m}$.

(A3). The size of $\mathrm{Ca}^{2+}$ responses evoked by adenosine was not statistically different from the size of responses evoked by ATP (Student $t$ test, $p>0.05$ ) (Table 1). These results indicate that adenosine receptors are present on the PSCs and suggest that $\mathrm{Ca}^{2+}$ responses evoked by ATP could be explained by the activation of adenosine receptors.

\section{Adenosine receptors are of the AI subtype}

To determine the type(s) of adenosine receptors, we first used antagonists of P1 receptors. The antagonists were perfused on the preparation for at least $20 \mathrm{~min}$ prior to local applications of adenosine. The presence of 1,3-dipropyl-8-cyclopentylxanthine (DPCPX) $(2 \mu \mathrm{M})$, a potent, specific Al receptor antagonist (Martinson et al., 1987; Linden, 1991; Müller and Scior, 1993) prevented the production of $\mathrm{Ca}^{2+}$ responses by adenosine in all cells tested (Fig. $3 A$; three muscles, 17 cells; $4 \pm 1 \%$ ). The average $\mathrm{Ca}^{2+}$ response amplitude in presence of DPCPX was signifi- cantly smaller than the one obtained with adenosine in absence of the antagonist (ANOVA analysis of variance, $p<0.05$ ). The lack of responses was unlikely due to nonspecific effects of DPCPX since $\mathrm{Ca}^{2+}$ responses were evoked by local application of the muscarinic agonist muscarine $(1 \mu \mathrm{M})$ in presence of the A1 antagonist (data not shown).

Similar results were obtained when 8-cyclopentyl-1,3-dimethylxanthine (CPT), another A1 antagonist (Bruns, 1990), was used. Indeed, $\mathrm{Ca}^{2+}$ responses evoked by adenosine were greatly reduced when CPT $(10 \mu \mathrm{M})$ was present in the perfusing solution (two muscles, 11 cells; $51 \pm 18 \%$ ) (Fig. $3 B$ ). These responses were significantly different from the responses obtained in absence of the antagonist (ANOVA analysis of variance, $p<$ 0.05 ). $\mathrm{Ca}^{2+}$ responses to local application of adenosine were restored after washout of the antagonist (Fig. 3B). At concentration of $100 \mathrm{nM}, \mathrm{CPT}$ still blocked $\mathrm{Ca}^{2+}$ responses induced by adenosine $(52 \pm 43 \%$; three muscles, 15 cells $)$. The use of large 
concentrations of A2 specific antagonists such as CP-66,713 (50 $\mu \mathrm{M})$ or CGS $15943(50 \mu \mathrm{M})$ (Linden, 1991) did not block $\mathrm{Ca}^{2+}$ responses induced by adenosine (data not shown).

$\mathrm{Ca}^{2+}$ responses induced by adenosine were also mimicked by an $\mathrm{Al}$ receptor agonist. The average increase in fluorescence evoked by $\mathrm{N}^{6}$-cyclopentyladenosine (CPA; $1 \mu \mathrm{M}$ ), a highly specific Al agonist, was similar to the ones obtained with adenosine (Fig. 3C; three muscles, 22 cells; $205 \pm 22 \%$ ). This valuc was not statistically different from the size of the $\mathrm{Ca}^{2+}$ responses obtained with adenosine (ANOVA analysis of variance, $p>$ $0.05)$. These results suggest that the adenosine receptors are of the Al type. A summary of the effects of Al agonists and antagonists is presented in Table 1 .

Adenosine releases $\mathrm{Ca}^{2+}$ from internal stores via PTX-sensitive G-proteins in PSCs

Al receptors are often coupled to G-proteins and regulate the release of $\mathrm{Ca}^{2+}$ from internal stores through $\mathrm{IP}_{3}$ receptors. To test whether adenosine receptors of the PSCs are coupled to a PTX-sensitive G-protein, muscles were incubated for 12-14 hr with $2 \mu \mathrm{g} / \mathrm{ml}$ of PTX, and the ability of adenosine to evoke $\mathrm{Ca}^{2+}$ responses was evaluated. No $\mathrm{Ca}^{2+}$ responses were evoked in PSCs by adenosine after PTX treatment (Fig. 3D; four muscles, 30 cclls; $23 \pm 9 \%$ ), in $95 \%$ of the cells tested. $\mathrm{Ca}^{2+}$ responses were significantly smaller than the ones obtained in absence of PTX (ANOVA, $p<0.05$ ) (Table 1).

It is unlikely that the lack of responses was due to the inability of PSCs to generate any responses after such treatment since local application of muscarine, known to release $\mathrm{Ca}^{2+}$ from internal stores via a PTX-insensitive mechanism (Jahromi et al. 1993), still induced $\mathrm{Ca}^{2+}$ responses after PTX treatment (data not shown). In addition, the presence of PTX at the nmjs was confirmed by the inability of adenosine to reduce the amount of transmitter released after treatment with PTX (Silinsky, 1975; Silinsky et al., 1990; Jahromi et al., 1993).

We next tested whether $\mathrm{Ca}^{2+}$ responses mediated by $\mathrm{Al}$ receptors are due to the release of $\mathrm{Ca}^{2+}$ from internal stores. Preparations were incubated in $0 \mathrm{Ca}^{2+}-5 \mathrm{mM} \mathrm{Mg}^{2+}$ physiological solution for $30 \mathrm{~min}$ prior to adenosine applications. $\mathrm{Ca}^{2+}$ responses could still be evoked by adenosine (Fig. $3 E$; three muscles, 19 cells), indicating that the source of $\mathrm{Ca}^{2+}$ was from internal stores and did not require the entry of $\mathrm{Ca}^{2+}$ into the PSCs. The size of $\mathrm{Ca}^{2+}$ responses $(159 \pm 26 \%)$ was not significantly different from the $\mathrm{Ca}^{2+}$ responses obtained in presence of external $\mathrm{Ca}^{2+}$ (Anova analysis of variance, $p<0.05$ ) (Table 1). Similar results were obtained when EGTA ( $1 \mathrm{~mm}$ ) was added to the physiological solution to further reduce external $\mathrm{Ca}^{2+}$ concentration (data not shown). Hence, these results indicate that $\mathrm{Al}$ receptors of the frog PSCs are coupled to PTX sensitive G-proteins which regulate the release of $\mathrm{Ca}^{2+}$ from internal stores.

\section{Are ATP receptors $(P 2)$ present on PSCs?}

Different $\mathrm{P} 2$ receptor agonists and antagonists were used to confirm the presence of ATP receptors on PSCs. The first attempts to test for the presence of $\mathrm{P} 2$ receptors on PSCs were performed using 2-methylthio-ATP (Me-S-ATP), an ATP analog which preferentially binds to $\mathrm{P}_{2 Y}$ receptors (Cusack and Hourani, 1990; Salter and Hicks, 1993; Burnstock et al., 1994). Local applications of Me-S-ATP $(20 \mu \mathrm{M})$ induced $\mathrm{Ca}^{2+}$ responses $(212 \pm$ $29 \%$ ) in all cells tested (three muscles; 31 cells). Figure $4, A$ and $B$, shows three PSC's at a nmj, before $(A I)$ and shortly after application of Me-S-ATP $(20 \mu \mathrm{M})(A 2)$. Similar to adenosine,
$\mathrm{Ca}^{2+}$ responses evoked by Me-S-ATP were not significantly different from the responses evoked by ATP (ANOVA, analysis of variance, $p>0.05$ ) (Table 1). It is possible that the responses evoked by Me-S-ATP are mediated through a $P_{2 \downarrow}$ receptor since this agonist has some affinity for the $P_{2 U}$ receptor (Salter and Hicks, 1994). This is unlikely since the application of UTP, the agonist for $\mathrm{P}_{2 U}$ receptor, did not evoke any $\mathrm{Ca}^{2+}$ responses in the PSCs (data not shown). However, because Me-S-ATP is hydrolyzable, it is possible that part of its effect was due to activation of adenosine receptors.

To further confirm the presence of ATP receptors on PSCs we used L-adenylyl 5'-( $\beta, \gamma$-methylene)diphosphate (L-AMP-PCP), an ATP analog with a higher affinity to $P_{2 X}$ receptors (Cusack and Hourani, 1990). On the contrary to Me-S-ATP, L-AMP-PCP is resistant to dephosphorylation (Hourani et al., 1986) and, hence, will prevent the formation of adenosine by the ecto-enzymes. Figure $4 C$ illustrates the changes of fluorescence induced by a local application of L-AMP-PCP $(50 \mu \mathrm{M})$. On average, $\mathrm{Ca}^{2+}$ responses evoked by L-AMP-PCP were $121 \pm 14 \%$ and all cells tested responded ( 6 muscles, 19 cells). $\mathrm{Ca}^{2+}$ responses evoked by L-AMP-PCP were significantly smaller than the responses evoked by ATP (ANOVA, $p<0.05$ ) (Table 1).

\section{Antagonists of $P 2$ receptors block $\mathrm{Ca}^{2+}$ responses induced by} ATP analogs

$\mathrm{Ca}^{2+}$ responses elicited by ATP agonists should be blocked by $\mathrm{P} 2$ receptor antagonists if they are due to the activation of ATP receptors and not adenosine receptors. $\mathrm{Ca}^{2+}$ responses could not be evoked by Me-S-ATP $(20 \mu \mathrm{M})$ in presence of suramin $(200$ $\mu \mathrm{M}$ ), a nonspecific P2 antagonist (Fig. $4 D$; four muscles, 22 cells; $19 \pm 6 \%$ ). Only $50 \%$ of the cells were blocked when suramin was used at a concentration of $100 \mu \mathrm{M}$. The blockade of $\mathrm{Ca}^{2+}$ responses by suramin was reversible and responses could be obtained after removal of the antagonist (Fig. $4 D$ ). Similarly, $\mathrm{Ca}^{2+}$ responses evoked by L-AMP-PCP $(50 \mu \mathrm{M})$ were reversibly blocked by suramin $(100 \mu \mathrm{M})$ (three muscles, 14 cells; $10 \pm 4 \%$ ) (Fig. $4 E$, Table 1). However, adenosine ( $10 \mu \mathrm{M})$ still induced $\mathrm{Ca}^{21}$ responses in presence of suramin $(215 \pm 20$; three muscles, six cells) (ANOVA, $p>0.05$ ) (Table 1). Moreover, $\mathrm{Ca}^{2+}$ responses elicited by ATP analogs were not blocked by the Al antagonist, DPCPX (Table 1) indicating that the adenosine receptors are not blocked by suramin. These results indicate that $\mathrm{Ca}^{2+}$ responses evoked by ATP and its agonists are likely due to the activation of $\mathrm{P} 2$ receptors.

The next step consisted in determining whether the two agonists act on the same $\mathrm{P} 2$ receptor or on different ones. To do so, the cellular mechanisms responsible for the production of the $\mathrm{Ca}^{2+}$ responses were examined. $\mathrm{P}_{2 Y}$ receptors would be expected to regulate the release of $\mathrm{Ca}^{2+}$ from internal stores whereas $\mathrm{P}_{2 \mathrm{X}}$ receptors are expected to mediate $\mathrm{Ca}^{2+}$ entry into the cells either directly through the receptor or by activating voltage-dependent $\mathrm{Ca}^{2+}$ channels due to membrane depolarization (Bean, 1992; Zimmerman, 1994).

\section{Me-S-ATP releases $\mathrm{Ca}^{2+}$ from internal stores via PTX-sensitive $G$-proteins in PSCs}

The cellular mechanisms involved in the responses induced by Me-S-ATP were first examined. PTX was used to determine whether a PTX-sensitive G-protein was involved in the production of the $\mathrm{Ca}^{2+}$ responses. After incubation with PTX $(2 \mu \mathrm{g} /$ $\mathrm{ml}), \mathrm{Ca}^{2+}$ responses evoked by Me-S-ATP $(20 \mu \mathrm{M})$ were greatly diminished (Fig. 5A) (four muscles, 48 cells; $29 \pm 6 \%$ ). $\mathrm{Ca}^{2}$ * 
A
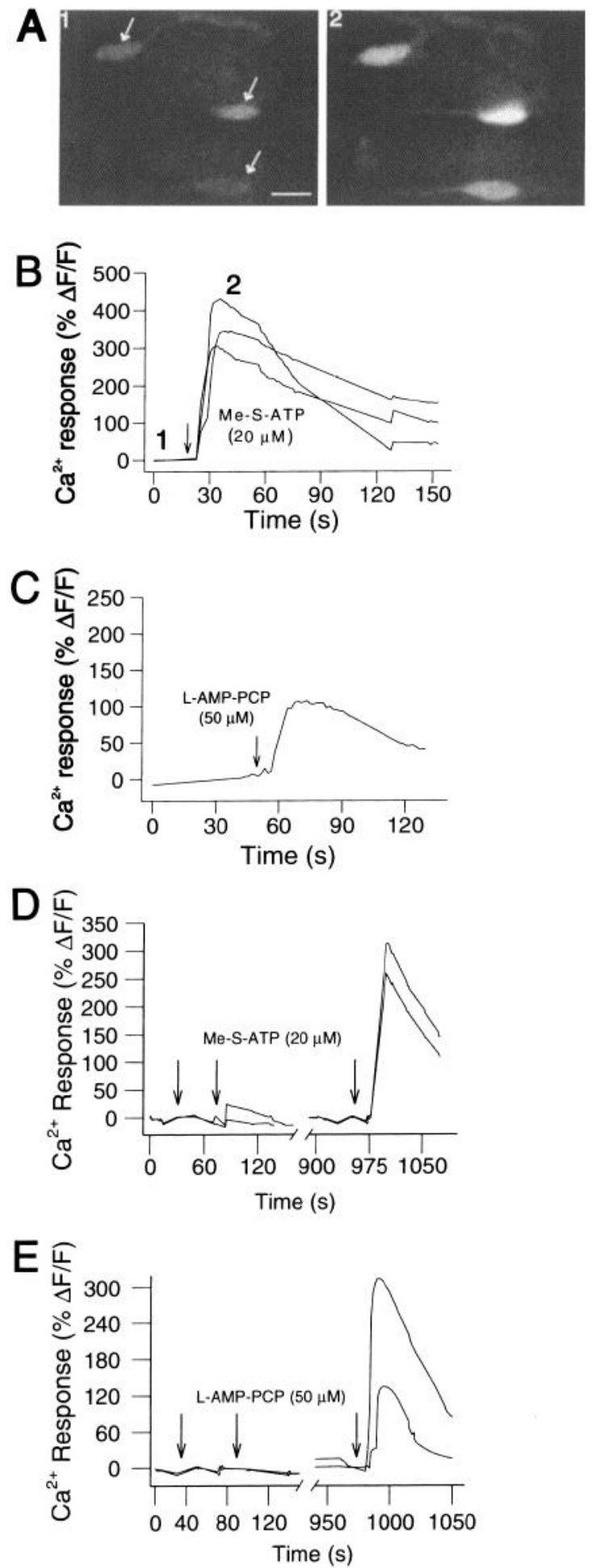

Figure 4. ATP agonists evoke $\mathrm{Ca}^{2+}$ responses in PSCs. A Images of three PSCs before ( $(1)$ and after (2) local application of Me-S-ATP (20 $\mu \mathrm{M})$, an ATP analog. Scale bar, $15 \mu \mathrm{m}$. $B$, Changes of fluorescence before and after local application (arrow) of Me-S-ATP $(20 \mu \mathrm{M})$ of the same cells illustrated in $A$. Each line on the graph illustrates the time course of the $\mathrm{Ca}^{2+}$ response for a PSC and the numbers indicate the respective time at which images in $A$ were taken. $C$, Changes in fluorescence in one PSC before and after local application (arrow) of L-AMP-PCP $(50 \mu \mathrm{M})$, a nonhydrolyzable analog of ATP. $D$, Changes of fluorescence before and after local applications (arrows) of Me-SATP $(20 \mu \mathrm{M})$ in presence of $200 \mu \mathrm{M}$ suramin, a P2 antagonist. After washout of the antagonist (break in the $\mathrm{x}$-axis), $\mathrm{Ca}^{2+}$ responses could responses were significantly smaller than the ones evoked in absence of PTX (ANOVA, $p<0.05$ ) (Table 1). However, muscarine $(1 \mu \mathrm{M})$ induced $\mathrm{Ca}^{2+}$ responses in the same cells confirming the ability of the cells to respond.

We next examined whether external $\mathrm{Ca}^{2+}$ was necessary for the responses induced by Me-S-ATP. In absence of external $\mathrm{Ca}^{2+}$ $\left(0 \mathrm{Ca}^{2+}-5 \mathrm{Mg}^{2+}\right), \mathrm{Me}-\mathrm{S}$-ATP evoked $\mathrm{Ca}^{2+}$ responses that were similar to the ones obtained in presence of external $\mathrm{Ca}^{2+}$ (Fig. $5 B)(184 \pm 27 \%$; three muscles, 19 cells) (ANOVA, $p>0.05$ ) (Table 1). Similar results were obtained when EGTA (1 mM) was added to the physiological solution (data not shown). Hence, Me-S-ATP induced the release of $\mathrm{Ca}^{2+}$ from internal stores via a PTX-sensitive G-protein. This is consistent with Me-S-ATP acting on $\mathrm{P}_{2 \mathrm{Y}}$ receptors.

\section{External $\mathrm{Ca}^{2+}$ is required for $\mathrm{Ca}^{2+}$ responses evoked by $L-A M P-P C P$}

If L-AMP-PCP and Me-S-ATP act via the same receptor but with different affinity, cellular mechanisms causing the $\mathrm{Ca}^{2+}$ responses should be the same. However, if L-AMP-PCP activates $\mathrm{P}_{2 \mathrm{X}}$ receptors, one would predict that $\mathrm{Ca}^{2+}$ responses would require $\mathrm{Ca}^{2+}$ entry into the cell (Burnstock, 1990; Salter et al., 1993). Furthermore, unlike $P_{2 Y}$ receptors, $P_{2 X}$ receptors are generally not coupled to G-proteins (Barnard et al., 1994).

The involvement of PTX-sensitive G-proteins was first tested. Local applications of L-AMP-PCP $(50 \mu \mathrm{M})$, still evoked $\mathrm{Ca}^{2+}$ responses after PTX treatment $(126 \pm 24 \%$; $16 / 17$ cells; Fig. $5 C$ ) (ANOVA, $p>0.05$ ) (Table 1). The absence of effect is not due to PTX inefficacy since no $\mathrm{Ca}^{2+}$ responses were evoked by adenosine on the same preparations (data not shown).

The requirement of external $\mathrm{Ca}^{2+}$ for the genesis of $\mathrm{Ca}^{2+}$ responses was tested by replacing $\mathrm{Ca}^{2+}$ ions by $\mathrm{Mg}^{2+}$ ions. $\mathrm{Ca}^{2+}$ responses evoked by L-AMP-PCP $(50 \mu \mathrm{M})$ were greatly reduced ( $25 \pm 9 \%$; three muscles, 20 cells) (Fig. $5 D$, Table 1). Upon addition of external $\mathrm{Ca}^{2+}$ (break in the x-axis), the ability of L-AMP-PCP $(50 \mu \mathrm{M})$ to evoke $\mathrm{Ca}^{2+}$ responses was restored (Fig. 5D). The entry of $\mathrm{Ca}^{2+}$ was further tested by using $\mathrm{Cd}^{2+}$ $(20 \mu \mathrm{M})$, an ion competing for many $\mathrm{Ca}^{2+}$-binding sites (Bean, 1992). $\mathrm{Ca}^{2+}$ responses evoked by L-AMP-PCP in presence of $\mathrm{Cd}^{2+}$ were significantly reduced $(12 \pm 8 \%$; three muscles, 19 cells; ANOVA, $p<0.05$ ) (Table 1). These results indicate that L-AMP-PCP induced $\mathrm{Ca}^{2+}$ entry via a PTX-insensitive mechanism and are consistent with the activation of $\mathrm{P}_{2 \mathrm{X}}$ receptors.

Hence, the different cellular mechanisms regulating $\mathrm{Ca}^{2+} \mathrm{re}-$ sponses evoked by Me-S-ATP and L-AMP-PCP suggest that $\mathrm{P}_{2 \mathrm{Y}}$ and $\mathrm{P}_{2 \mathrm{X}}$ receptors are present on PSCs.

\section{L-AMP-PCP mediates $\mathrm{Ca}^{2+}$ entry mainly through L-type $\mathrm{Ca}^{2+}$ channels}

The possible involvement of $\mathrm{Ca}^{2+}$ channels in the entry of $\mathrm{Ca}^{2+}$ induced by L-AMP-PCP was next investigated. $\mathrm{Ca}^{2+}$ channels are present in many glial cells and in PSCs in particular (Barres et al., 1990; MacVicar et al., 1991; Jahromi et al., 1992) and could be activated by membrane depolarisation induced by ions

$\leftarrow$

be induced by Me-S-ATP on the same cells. $E$, Changes of fluorescence before and after local applications (arrows) of L-AMP-PCP $(50 \mu \mathrm{M})$ in presence of $100 \mu \mathrm{M}$ suramin. $\mathrm{Ca}^{2+}$ responses could be evoked in the same cells after removal of the antagonist (break in the x-axis). Each line on the graphs illustrates the time course of the $\mathrm{Ca}^{2+}$ response for a PSC. Different preparation than $D$. 

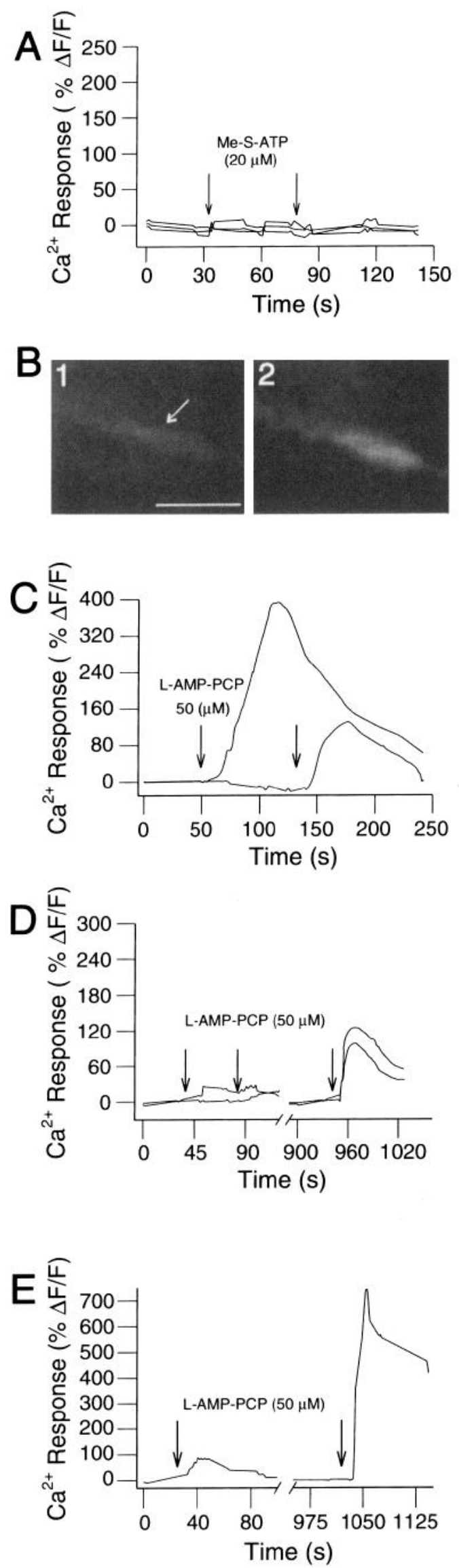

Figure 5. Cellular mechanisms of $\mathrm{Ca}^{2+}$ responses triggered by ATP agonists. $A$, Changes of fluorescence in three PSCs before and after entering the cells through $\mathrm{P}_{2 \mathrm{x}}$ receptors. The ability of L-AMPPCP to evoke $\mathrm{Ca}^{2+}$ responses was monitored in presence of various L-type $\mathrm{Ca}^{2+}$ channel antagonists, the most common $\mathrm{Ca}^{2+}$ channels in glial cells (Barres et al., 1990; MacVicar et al., 1991). In the presence of the antagonist enantiomer of Bay $\mathrm{K}$ 8644, R(+) Bay K $8644(2-20 \mu \mathrm{M})$, (Ferrante et al., 1989; van Amsterdam et al., 1989; Ravens et al., 1990), $\mathrm{Ca}^{2+}$ responses induced by L-AMP-PCP $(50 \mu \mathrm{M})$ were reduced by $80 \%$ (five cells, three muscles; $25 \pm 12 \%$ ) (Table 1 ). This reduction was reversible upon washout of the $\mathrm{Ca}^{2+}$ channel antagonist. Similar results were obtained with nimodipine $(2 \mu \mathrm{M})$ (Robitaille et al., 1995). These results indicate that $\mathrm{Ca}^{2+}$ entry induced by L-AMP$\mathrm{PCP}$, likely due to $\mathrm{P}_{2 \mathrm{X}}$ receptor activation, is mainly the result of L-type $\mathrm{Ca}^{2+}$ channels activation due to membrane depolarization.

\section{Modulation of $\mathrm{Ca}^{2+}$ responses by endogenous purines}

The involvement of endogenous purines in triggering $\mathrm{Ca}^{2+}$ responses in PSCs during synaptic transmission was next examined. Transmitter release was evoked by repetitive stimulations of the motor nerve at $50 \mathrm{~Hz}$. On average, $\mathrm{Ca}^{2+}$ responses were $326 \pm 59 \%$ (three muscles, seven cells) (Table 1), the delay before the onset was $3.3 \pm 0.5 \mathrm{sec}$ and the time to reach the maximum amplitude was $19 \pm 5 \mathrm{sec}$ (Fig. $6 A, B$ ). As shown in our previous study (Jahromi et al., 1992), nerve-evoked $\mathrm{Ca}^{2+}$ responses show a progressive rundown during successive stimulations (Fig. 6C, solid circles). Because of that characteristic, the effects of different blockers on nerve-evoked $\mathrm{Ca}^{2+}$ responses were tested on different preparations and each preparation was only stimulated once.

The presence of the A1 antagonist DPCPX $(20 \mu \mathrm{M})$ had no effect on any of the parameters of the $\mathrm{Ca}^{2+}$ responses evoked by nerve stimulations (average of $396 \pm 69 \%$, delay of $4.1 \pm$ $1.2 \mathrm{sec}$, time to peak of $17 \pm 6 \mathrm{sec}$; three muscles, six cells). However, $\mathrm{Ca}^{2+}$ responses evoked by local applications of adenosine were blocked in these conditions, indicating that the adenosine receptors were blocked. Because A1 receptors often produce inhibitory actions (Silinsky et al., 1990; Edwards and Gibb, 1993), we hypothesized that the rundown of $\mathrm{Ca}^{2+}$ responses could be caused by the activation of Al receptors. As shown in

\section{$\leftarrow$}

local applications (arrows) of Me-S-ATP $(20 \mu \mathrm{M})$ following $13 \mathrm{hr}$ of incubation with PTX $(2 \mu \mathrm{g} / \mathrm{ml})$. Each trace on the graphs illustrates the time course of the $\mathrm{Ca}^{2+}$ response for a PSC. Note that no $\mathrm{Ca}^{2+}$ responses were evoked in these conditions. B, Images of one PSC (arrow) before (1) and after (2) application of Me-S-ATP $(20 \mu \mathrm{M})$ following $30 \mathrm{~min}$ of perfusion with $0 \mathrm{Ca}^{2+}-5 \mathrm{Mg}^{2+}$ physiological solution. Note the increase in fluorescence intensity of the PSC indicating an increase in intracellular $\mathrm{Ca}^{2+}$. Different preparation than $A$. Scale bar, $15 \mu \mathrm{m}$. $C$, Changes of fluorescence in two PSCs before and after local applications (arrows) of L-AMP-PCP $(50 \mu \mathrm{M})$ following $16 \mathrm{hr}$ incubation with PTX $(2 \mu \mathrm{g} / \mathrm{ml})$. Note the increase of fluorescence even after PTX treatment. $D$, Changes of fluorescence in two PSCs before and after local applications (arrows) of L-AMP-PCP $(50 \mu \mathrm{M})$ following $30 \mathrm{~min}$ of perfusion with $0 \mathrm{Ca}^{2+}-5 \mathrm{Mg}^{2+}$ physiological solution. $\mathrm{Ca}^{2+}$ responses could be induced in the same cells when external $\mathrm{Ca}^{2+}$ was reintroduced in the perfusate (break in the $\mathrm{x}$-axis). Each trace on the graphs illustrates the time course of the $\mathrm{Ca}^{2+}$ response for a PSC. Different preparation than $C$. E, Changes of fluorescence of a PSC before and after local application (arrow) of L-AMP-PCP $(50 \mu \mathrm{M})$ following $30 \mathrm{~min}$ of perfusion with $\mathrm{R}(+)$-Bay $\mathrm{K} 8644(2 \mu \mathrm{M})$, an L-type $\mathrm{Ca}^{2+}$ channel antagonist. A small $\mathrm{Ca}^{2+}$ response was observed. After removal of the antagonist (break in the $\mathrm{x}$-axis), local application of L-AMP-PCP $(50 \mu \mathrm{M})$ on the same cell induced a larger $\mathrm{Ca}^{2+}$ response. 

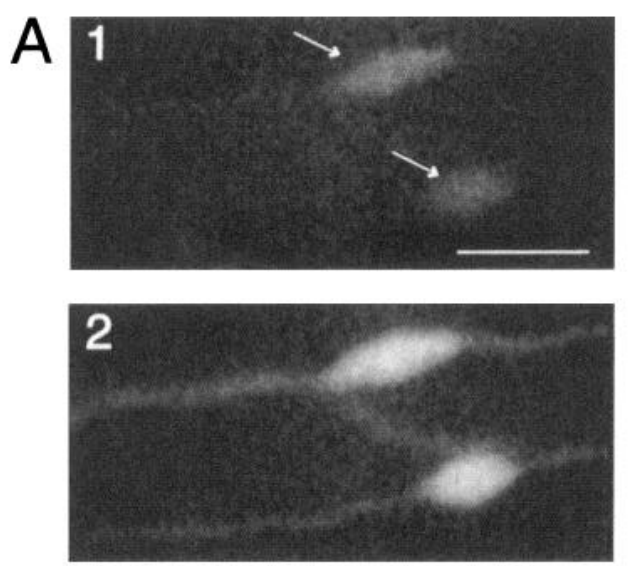
adenosine modulates nerve-evoked $\mathrm{Ca}^{2+}$ responses of the PSCs. A, Images of two PSCs before ( $I$ ), during (2), and after (3) sustained transmitter release evoked by repetitive stimulations of the motor nerve $(50 \mathrm{~Hz}) . B$, Graph of changes in fluorescence of the same PSCs as in $A$, before during and after repetitive motor nerve stimulation $(50 \mathrm{~Hz}$, bar). The numbers illustrated on the graph indicate at which time the corresponding figure in $A$ was taken. $C$, Normalized $\mathrm{Ca}^{2+}$ fluorescence expressed as a percentage of the $\mathrm{Ca}^{2+}$ response evoked by the first train of stimuli. Solid circles represent the rundown of $\mathrm{Ca}^{2+}$ responses for control preparations (seven cells, three muscles) and the solid squares represent the rundown of $\mathrm{Ca}^{2+}$ responses evoked in presence of the $\mathrm{A} 1$ antagonist DPCPX $(20 \mu \mathrm{M})$ (four cells, three muscles). Different muscles were used for each experiment. Note that the rundown is unaffected by the $\mathrm{Al}$ antagonist. $D$, Changes in fluorescence of a PSC before during and after repetitive motor nerve stimulation $(50 \mathrm{~Hz}$, bar) following $30 \mathrm{~min}$ perfusion with suramin $(200$ $\mu \mathrm{M})$, a P2 antagonist. The grey zone illustrates the mean and SE of nerveevoked $\mathrm{Ca}^{2+}$ responses obtained in absence of the antagonist. Note the delay in the onset of the response (the changes of fluorescence occured after the stimulation had stopped). This response is the second largest response observed in presence of suramin (seven cells, five muscles). Scale bar, $25 \mu \mathrm{m}$.
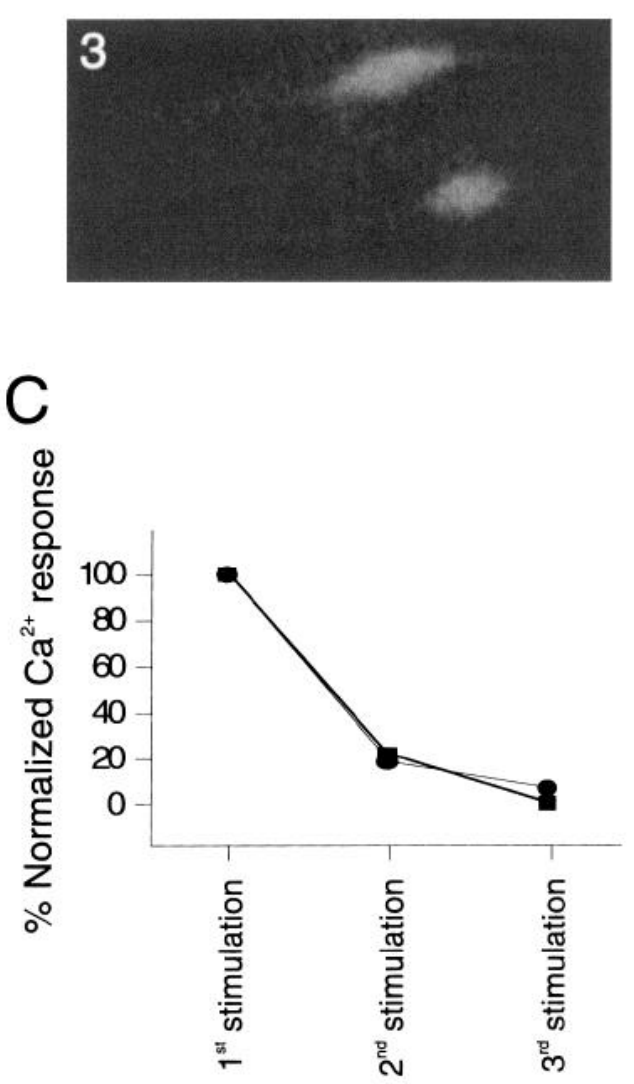

Figure 6. Endogenous ATP but not

Figure $6 C$ (solid squares; four cells, three muscles), the rate of rundown as well as the degree of attenuation was the same whether Al receptors were blocked or not. Thus, these results suggest that adenosine receptors do not modulate directly the $\mathrm{Ca}^{2+}$ responses induced by nerve evoked transmitter release.

We next tested whether ATP receptors modulate nerve-evoked $\mathrm{Ca}^{2+}$ responses of the PSCs. Blockade of ATP receptors with suramin $(200 \mu \mathrm{M})$ produced major changes in $\mathrm{Ca}^{2+}$ responses evoked by nerve stimulations (Fig. $6 D$ ). $\mathrm{Ca}^{2+}$ responses were reduced to $87 \pm 45 \%$ (five muscles, seven cells), which is statistically different from the control value (ANOVA, $p<0.05$ ) (Table 1). In addition, the delay before the onset of the responses was significantly increased to $16 \pm 4 \mathrm{sec}$, but the time to reach the maximum amplitude was not significantly different $(14 \pm 3$ sec; ANOVA, $p>0.05)$. The effect on the rundown of the $\mathrm{Ca}^{2+}$ responses could not be tested convincingly because the initial responses would often be too small. On four cells tested, aden-
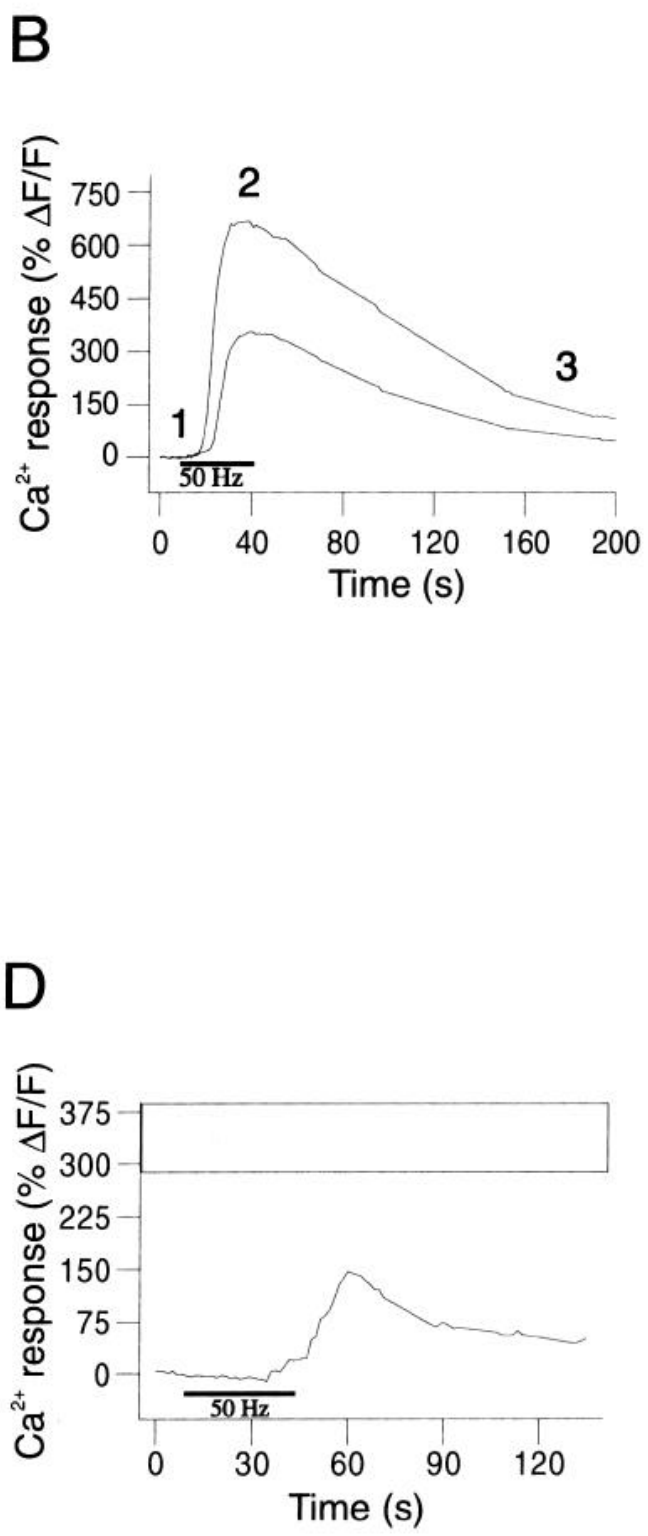

osine $(10 \mu \mathrm{M})$ could still evoke $\mathrm{Ca}^{2+}$ responses after the train of stimuli indicating that the cells were responsive and that the suramin effects are not due to blockade of adenosine receptors. These experiments indicate that the activation of ATP receptors, but not adenosine receptors, is necessary for optimal $\mathrm{Ca}^{2+}$ responses in the PSCs during synaptic transmission.

\section{Discussion}

The results of the present study reveal the presence of various purinoceptors at PSCs of the frog $\mathrm{nmj}$ and that these receptors are activated by endogenous ATP released by the nerve terminal during synaptic activity.

\section{Different purinoceptors on the PSCs}

Although the complete pharmacological characterization of the purinoceptors could not be achieved due to the presence of ectoenzymes (Smith, 1991) and the difficulty to block them all ( $\mathrm{Zi}$ - 
ganshin et al., 1993), the results of the present study support the fact that there are several types of purinoceptors in PSCs. For instance, the cellular mechanisms generating the $\mathrm{Ca}^{2+}$ responses vary according to the agonist used. L-AMP-PCP mediates $\mathrm{Ca}^{2+}$ entry whereas adenosine and Me-S-ATP induce the release of $\mathrm{Ca}^{2+}$ from internal stores. Moreover, the action of P1 and P2 receptor blockers is specific for their respective receptor type. This rules out possible actions of ATP agonists on adenosine receptors and strongly suggest that ATP and adenosine receptors are present in PSCs.

The characterization of $\mathrm{P} 2$ receptors is difficult owing to the lack of specific agonists and antagonists. However, the different cellular mechanisms producing the $\mathrm{Ca}^{2+}$ responses suggest that there are two types of ATP receptors on PSCs. Responses induced by Me-S-ATP correspond more to a $\mathrm{P}_{2 \mathrm{Y}}$ receptor as suggested by the release of $\mathrm{Ca}^{2+}$ from internal stores via G-protein mechanisms whereas responses induced by L-AMP-PCP correspond more to a $\mathrm{P}_{2 \times}$ receptor owing to the induction of $\mathrm{Ca}^{2+}$ entry directly through the receptors and L-type $\mathrm{Ca}^{2+}$ channels. Hence, we conclude that PSCs at the frog nmj have three types of purinoceptors which mediate $\mathrm{Ca}^{2+}$ responses.

\section{Specificity of pharmacological agents}

The pharmacological tools available to study ATP receptors are limited and their specificity of action is not always clear. For instance, suramin has been shown to inhibit ecto-ATPase activity (Voogd et al., 1993; Ziganshin et., 1994) and 5'-adenylylimidodiphosphate (AMP-PNP), an ATP analog related to L-AMPPCP, has been found to inhibit the activity of ecto-ADPase (James and Richardson, 1993). In both cases, endogenous ATP or locally applied ATP would remain in the synaptic cleft longer and, hence, show more potency activating all $\mathrm{P} 2$ receptors. This is unlikely in the present study since $\mathrm{Ca}^{2+}$ responses were completely and reversibly blocked by suramin, indicating that ATP receptors were blocked. Moreover, the mechanisms producing $\mathrm{Ca}^{2+}$ responses induced by L-AMP-PCP are different from the responses evoked by $\mathrm{Me}-\mathrm{S}-\mathrm{ATP}$, suggesting a specific action at $\mathrm{P}_{2 X}$ receptors.

The presence of ectoprotein-kinases on the surface of several cells (Ehrlich et al., 1986, 1994; Zimmermann, 1994) raises the possibility that $\mathrm{Ca}^{2+}$ responses induced by ATP are secondary to the action of an ectoprotein-kinase. This is unlikely because $\mathrm{Ca}^{2+}$ responses were obtained in absence of $\mathrm{Mg}^{2+}$, a cation required for the function of the enzyme (Ehrlich et al., 1986). Moreover, $\mathrm{Ca}^{2+}$ responses induced by ATP analogs were blocked by suramin, which further supports the involvement of ATP receptors.

Adenosine receptor pharmacology is better characterized (Daly et al., 1985; Hourani et al., 1986; Martinson et al., 1987; Bruns, 1990; Paton and Taerum, 1990; Linden, 1991; Stiles, 1992; Müller and Scior, 1993). The present results are consistent with the adenosine receptor being of the A1 subtype since A2 antagonists had no effects on $\mathrm{Ca}^{2+}$ responses evoked by adenosine whereas the responses were blocked by Al antagonists and mimicked by an Al agonist at concentrations similar or lower than the ones used in other studies (Silinsky et al., 1990; Meriney and Grinnell, 1992; Kriegler and Chiu, 1993; Salter et al., 1993; Sanger et al., 1993; Abbracchio et al., 1994).

\section{Implications of multiple purinoceptors at PSCs}

ATP has been shown to mediate fast synaptic responses in several neuronal preparations (Edwards et al., 1992; Evans et al.,

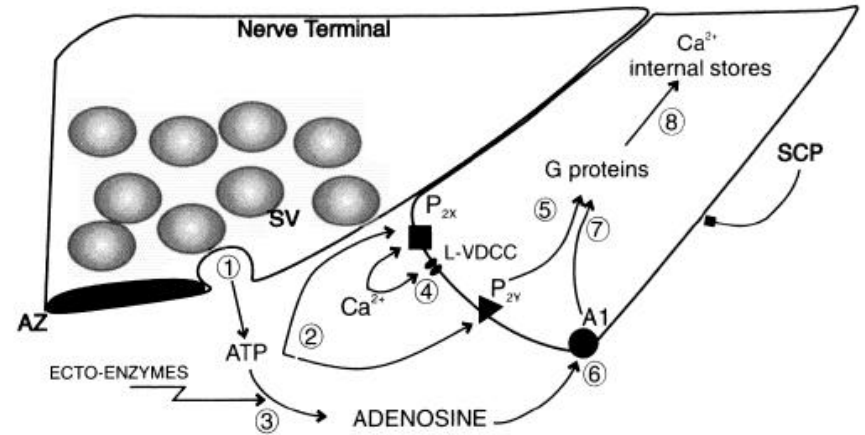

Figure 7. Model of purinoceptor activation at PSCs of frog nmj. Diagram illustrating a portion of a nerve terminal at an active zone $(A Z)$ surrounded by synaptic vesicles $(S V)$. A Schwann cell process $(S C P)$ is located at proximity of the active zone. The postsynaptic element has been omitted for clarity. ATP is coreleased with ACh during synaptic transmission $(I)$ and can activate $\mathrm{P}_{2 \times}$ and $\mathrm{P}_{2 Y}$ receptors (2). ATP will also be degraded to adenosine by the various ecto-enzymes (3). Activation of $\mathrm{P}_{2 \times}$ receptors by ATP will induce $\mathrm{Ca}^{2+}$ entry partly through the ATP receptor itself but mainly through L-type $\mathrm{Ca}^{2+}$ channels (4). Activation of $\mathrm{P}_{2 Y}$ receptors by ATP will trigger the release of $\mathrm{Ca}^{2+}$ from internal stores through the activation of a PTX-sensitive G-protein $(5,8)$. Activation of Al adenosine receptors (6) will result in the release of $\mathrm{Ca}^{2+}$ from internal stores mediated by the activation of a PTX-sensitive G-protein (7-8).

1992; Edwards and Gibb, 1993; Salter et al., 1993; Backus et al., 1994; Chen et al., 1994; Zimmermann, 1994) and, hence, ATP released during nerve-evoked synaptic transmission may also quickly activate the PSCs. In the present study, it is shown that endogenous ATP released during synaptic transmission modulates the activity of the PSCs. This regulatory effect of ATP is probably underestimated since the activation of the muscle fibers, providing approximately $50 \%$ of the total ATP (Smith, 1991), was prevented by blocking the postsynaptic receptors.

The presence of multiple purinoceptors implies that ATP activates multiple cellular pathways and control various cellular functions. Owing to the nature of the various cellular mechanisms and the enzymatic cascade required to produce adenosine from ATP, one may propose the following scheme.

Upon release from the nerve terminal (Fig. 7, step 1), ATP may act directly on two different receptors, $\mathrm{P}_{2 \mathrm{X}}$ and $\mathrm{P}_{2 \mathrm{Y}}$ ( (step 2). ATP will also be dephosphorylated by the ecto-enzymes to form adenosine (step 3). It is quite likely that $\mathrm{Ca}^{2+}$ entry mediated by the $\mathrm{P}_{2 X}$ receptors will occur prior to $\mathrm{Ca}^{2+}$ released by the activation of $P_{2 Y}$ receptors because $P_{2 X}$ receptors are directly permeable to $\mathrm{Ca}^{2+}$ and indirectly activate $\mathrm{L}$-type $\mathrm{Ca}^{2+}$ channels (step 4) whereas $P_{2 Y}$ receptors act by a slow process involving $\mathrm{Ca}^{2+}$ release from internal stores via second messengers and G-protein activation (steps 5 and 8) (Barnard et al., 1994; Burnstock et al., 1994). Due to ATP and ADP inactivation of 5'nucleotidase (Zimmermann, 1992, 1994) causing delay in the apparition of adenosine, the activation of adenosine receptors (step 6) would occur later, after degradation of ATP. It will also lead to the activation of a G-protein (step 7) and the release of $\mathrm{Ca}^{2+}$ from internal stores (step 8), provided that the stores were not depleted by the activation of $\mathrm{P}_{2 \mathrm{Y}}$ receptors. The activation of adenosine receptors is hypothetical since no evidence was obtained in the present study. A1 and P2 receptors likely have different regulating mechanisms since ATP but not adenosine antagonists modulated the nerve-evoked $\mathrm{Ca}^{2+}$ responses in PSCs. We hypothesize that the early activation of $\mathrm{P}_{2 \mathrm{X}}$ receptors engages a cascade of events that will be completed or terminated 
by the activations of $P_{2 Y}$ or adenosine receptors or both. This possibility is supported by the observations that different purinoceptors may have opposite effects on the cellular functions (Boland et al., 1992; Abbracchio et al., 1994).

\section{Actions of purines on glial cells}

Adenosine and ATP receptors are widely distributed (Burnstock, 1990; Olsson and Pearson, 1990; Schwabe et al., 1991; Salter et al., 1993) and are present on several types of glial cells such as cultured astrocytes (Gebicker-Haerter et al., 1988; Neary et al., 1988; Meghji et al., 1989; Lai and Wong, 1991; Kastritsis et al., 1992; Salter and Hicks, 1994), oligodendrocytes (Meghji et al., 1989), glioma cells (Lin and Chuang, 1993; Chueh et al., 1994), microglial cells (Walz et al., 1994), and glial cells of the rat optic nerve (Kriegler and Chiu, 1993). Among other roles, purinoceptors control the synthesis of prostaglandin (GebickeHaerter et al., 1988) and thromboxane A2 (Pearce and Murphy, 1988), and regulate protein phosphorylation and dephosphorylation (Neary et al., 1991). I yons et al. (1995) showed that ATPmediated $\mathrm{Ca}^{2}$ responses in myelinating Schwann cells were dependent on direct contact with neurons. Although numerous other functions and roles have been attributed to the activation of purinoceptors (see Kastritsis et al., 1992, for discussion), it is difficult to determine the actions of the purinoceptors in frog PSCs because very little is known about their functions. A recent observation suggests that ATP and adenosine receptors are not involved in PSC regulation the same way muscarinic receptors are. Indeed, we recently found that muscarinic receptors, but not purinoceptors, can prevent the upregulation of glial fibrilary acidic protein in the frog PSCs induced by the interuption of synaptic activity (Georgiou et al., I994a,b).

\section{Possible modulation of synaptic functions}

The most appealing potential roles of the purinoceptors are the ones that may affect synaptic activity or the maintenance and support of synaptic integrity. For example, it has been reported that adenosine and ATP modulate transmitter release at the frog nmj (Silinsky, 1975; Silinsky, 1980; Silinsky et al., 1990; Vizi et al., 1990; Meriney and Grinnell, 1992; Fu and Huang, 1994). In the context of the present work, and the evidence of glial modulation of nerve cell activity (Parpura et al., 1994), and the possible rapid neuron-glia signaling (Murphy ct al., 1993), wc postulate that the effects of purines on synaptic activity may be mediated in part by perisynaptic glial cells. Indeed, experiments demonstrating the effects of purines on synapses were not performed in a way to rule out any modulation by perisynaptic glial cells. The presence of functional purinoceptors at PSCs reinforce the idea that the actions of purines on synaptic functions could be mediated by perisynaptic glial cells. Perisynaptic glial cells in the CNS could also be activated by endogenous purines and, hence, may be involved in the ATP-mediated modulation of synaptic activity (Salter et al., 1993).

\section{References}

Abbracchio MP, Saffrey MJ, Hopker V, Burnstock G (1994) Modulation of astroglial cell proliferation by analogues of adenosine and ATP in primary cultures of rat striatum. Neuroscience 59:67-76.

Arslan P, Di Virgilio F, Beltrame M, Tsien RY, Pozzan T (1985) Cytosolic $\mathrm{Ca}^{2+}$ homeostasis in Ehrlich and Yoshida carcinomas. J Biol Chem 260:2719-2727.

Backus KH. Braum S. Lohner F, Deitmer JW (1994) Neuronal responses to purinoceptor agonists in the leech central nervous system. J Neurobiol 25:1283-1292.
Barnard EA (1992) Receptor classes and the transmitter-gated ion channels. Trends Biol Sci 17:368-374.

Barnard EA, Burnstock G, Webb TE (1994) G protein-coupled receptors for ATP and other nucleotides: a new receptor family. Trends Pharmacol Sci 15:67-70.

Barres BA, Chun LLY, Corey DP (1990) Ion channels in vertebrate glia. Annu Rev Neurosci 13:441-474.

Bean BP (1992) Pharmacology and electrophysiology of ATP-activated ion channels. Trends Pharmacol Sci 13:87-90.

Benham CD (1989) ATP activated channels gate calcium entry in single smooth muscle cells dissociated from rabbit ear artery. J Physiol (Lond) 419:689-701

Boland B, Himpens B, Vincent MF, Gillis JM. Casteels R (1992) ATP activates $P_{2 X}$-contracting and $P_{2 Y}$-relaxing purinoceptors in the smopth muscle of mouse vas deferens. Br J Pharmacol 107:11521158.

Bruns RF (1990) Adenosine receptors: roles and pharmacology. Ann NY Acad Sci 603:211-226.

Burnstock G (1990) Purinergic mechanisms. Ann NY Acad Sci 603: $1-18$.

Burnstock G, Fisher B, Hoyle CHV, Maillard M, Ziganshin AU, Brizzolara AL, von Isakovics A, Boyer JL, Harden TK, Jacobson KA (1994) Structure activity relationships for derivatives of adenosine5'-triphosphate as agonists at $P_{2}$ purinoceptors: heterogeneity within $P_{2 x}$ and $P_{2 \gamma}$ subtypes. Drug Dev Res 31:206-219.

Chen ZP, Levy A, Lightman SL (1994) Activation of specific ATP receptors induces a rapid increase in intracellular calcium ions in rat hypothalamic neurons. Brain Res 641:249-256.

Chiu SY, Kriegler S (1994) Neurotransmitter-mediated signaling between axons and glial cells. Glia 11:19]-200.

Chueh S-H, Hsu L-S, Song SI (1994) Two distinct ATP signaling mechanisms in differentiated neuroblastoma $\times$ glioma hybrid NG108-15 cells. Mol Pharmacol 45:532-539

Cusack NJ, Hourani SMO (1990) Subtypes of $P_{2}$-purinoceptors. Ann NY Acad Sci 603:172-181

Daly JW, Padgett W, Shamim MT, Butts-Lamb P, Waters J (1985) 1,3Dialkyl-8-( $p$-sulfophenyl)xanthines: potent water-soluble antagonists for $\mathrm{A}_{1}$ and $\mathrm{A}_{2}$-adenosine receptors. J Med Chem 28:487-492.

Dani JW, Chernjavsky A, Smith SJ (1992) Neuronal activity triggers calcium waves in hippocampal astrocyte networks. Neuron 8:429440.

Edwards FA, Gibb AJ (1993) ATP-a fast neurotransmitter. FEBS 325: 86-89.

Edwards FA, Gibb AJ, Colquhoun D (1992) ATP receptor-mediated synaptic currents in the central nervous system. Nature 359:144-147.

Ehrlich YH, Davis TB, Bock E, Kornecki E, Lenox R (1986) Ectoprotein kinase activity on the external surface of neural cells. Nature 320:67-70.

El-Moatassim C, Dornand J, Mani J-C (1992) Extracellular ATP and cell signalling. Biochim Biophys Acta 1134:31-45.

Evans RJ, Derkach V, Surprenant A (1992) ATP mediates fast synaptic transmission in mammalian neurons. Nature 357:503-505.

Ferrante J, Luchowski E, Rutledge A. Triggle DJ (1989) Binding of a 1,4-dihydropyridine calcium channel activator (-) S Bay K 8644, to cardiac preparations. Biochem Biophys Res Commun 158:149-154.

Fu W-M, Huang F-L (1994) Potentiation by endogenously released ATP of spontaneous transmitter secretion at developing neuromuscular synapses in Xenopus cell cultures. Br J Pharmacol 111:880886.

Gebicker-Haerter PJ, Wurster S, Schobert A, Hertting G (1988) $P_{2-}$ purinoceptor induced prostaglandin synthesis in primary rat astrocyte cultures. Naunyn-Schmiedeberg's Arch Pharmacol 338:704-707.

Georgiou J, Robitaille R, Charlton MP (1994a) Muscarine, but not ATP regulates GFAP expression in synaptic glia. Soc Neurosci Abstr 20 : 708.

Georgiou J, Robitaille R, Trimble WS, Charlton MP (1994b) Synaptic regulation of glial protein expression in vivo. Neuron 12:44.3-455.

Hamprecht, B (1986) Astroglia cells in culture: receptors and cyclic nucleotides. In: Astrocytes (Fedoroff S, Vernadakis A, eds), pp 77106. Orlando, FL: Academic.

Hourani SMO, Loizou GD, Cusack NJ (1986) Pharmacological effects of L-AMP-PCP on ATP receptors in smooth muscle. Eur J Pharmacol 131:99-103.

Jahromi BS, Robitaille R, Charlton MP (1992) Transmitter release in- 
creases intracellular calcium in perisynaptic Schwann cells in situ. Neuron 8:1069-1077.

Jahromi BS, Robitaille R, Charlton MP (1993) Muscarinic $\mathrm{Ca}^{2+}$ responses unaffected by muscarinic antagonists. Soc Neurosci Abstr 19:463.

James S. Richardson PJ (1993) Production of adenosine from extracellular ATP at the striatal cholinergic synapse. J Neurochem 60:219227.

Kao JPY, Harootunian AT, Tsien RY (1989) Photochemically generated cytosolic calcium pulses and their detection by fluo-3. J Biol Chem $264: 8179-8184$

Kastritsis CHC, Salm AK, McCarthy K (1992) Stimulation of the P2Y purinergic receptor on type 1 astroglia results in inositol phosphate formation and calcium mobilization. J Neurochem 58:1277-1284

Kriegler S, Chiu SY (1993) Calcium signaling of glial cells along mammalian axons. J Neurosci 13:4229-4245.

Lai K-M, Wong PCL (1991) Metabolism of extracellular adenine nucleotides by cultured rat brain astrocytes. J Neurochem 57:15101515.

Lin W-W. Chuang D-M (1993) Agonist-induced desensitization of ATP receptor-mediated phosphoinositide turnover in $\mathrm{C}_{6}$ glioma cells: comparison with the negative-feedback regulation by protein kinase $\mathrm{C}$. Neurochem Int 23:53-60.

Linden J (1991) Structure and function of $A_{1}$ adenosine receptors. FASEB J 5:2668-2676.

I.indgren CA, Smith DO (1987) Extracellular ATP modulates calcium uptake and transmitter release at the neuromuscular junction. J Neurosci 7:1567-1573.

Lyons S A, Morell P, McCarthy KD (1995) Schwann cell ATP-mediated calcium increases in vitro and in situ are dependent on contact with neurons. Glia 13:27-38.

MacVicar BA. Hochunan D, Delay MJ, Weiss S (1991) Modulation of intracellular $\mathrm{Ca}^{++}$in cultured astrocytes by influx through voltage activated $\mathrm{Ca}^{++}$channels. Glia 4:448-455.

Martinson EA, Johnson RA, Wells JN (1987) Potent adenosine receptor antagonists that are selective for the $A_{1}$ receptor subtype. Mol Pharmacol 31:247-252.

Meghji P, Tuttle JB, Rubio R (1989) Adenosine formation and release by emvryonic chick neurons and glia in cell culture. J Neurochem $53: 1852-1860$.

Meriney SD. Grinnell AD (1991) Endogenous adenosine modulates stimulation-induced depression at the frog neuromuscular junction. $\mathbf{J}$ Physiol (Lond) 143:141-155.

Müller CE, Scior T (1993) Adenosine receptors and their modulators. Pharm Acta Helv 68:77-111.

Murphy TH, Blatter LA, Wier WG, Baraban JM (1993) Rapid communication between neurons and astrocytes in primary cortical cultures. J Neurosci 13:2672-2679.

Neary JI, van Breemen C, Forster E, Norenberg LOB, Norenberg MD (1988) ATP stimulates calcium influx in primary astrocytes. Biochem Biophys Res Commun 157:1410-1416.

Neary JT, Laskey R, van Breemen C, Blicharska J, Norenberg LOB, Norenberg MD (1991) ATP-evoked calcium signal stimulates protein phosphorylation/dephosphorylation in astrocytes. Brain Res 566: 89-94.

O'Connor SE, Dainty IA, Leff P (1991) Further subclassification of ATP receptors based on agonist studies. Trends Pharmacol Sci 12: 1.37-141.

Olsson RA, Pearson JD (1990) Cardiovascular purinoceptors. Physiol Rev 70:761-845

Parpura V, Basarsky TA, Liu F, Jeftinija K, Jeftinija S, Haydon PG (1994) Glutamate-mediated astrocyte-neuron signalling. Nature 369: $744-74 \%$

Paton DM. Taerum $T$ (1990) A comparison of $P_{1}$ - and $P_{2}$-purinoceptors. Ann NY Acad Sci 603:165-171.
Pearce B, Murphy S (1988) Neurotransmitter receptors coupled to inositol phospholipid turnover and $\mathrm{Ca}^{2+}$ flux: consequences for astrocytes function. In: Glial cell receptors (Kimelberg HK, ed), pp 197221.

Ravens U, Schopper HP (1990) Opposite cardiac actions of the enantiomer of Bay K 8644 at different membrane potentials in guinea-pig papillary muscles. Naunyn-Schmiedeberg's Arch Pharmacol 341: 232-239.

Reist NE, Smith SJ (1992) Neurally evoked calcium transients in terminal Schwann cells at the neuromuscular junction. Proc Natl Acad Sci USA 89:7625-7629.

Robitaille $\mathrm{R}$ (1994) $\mathrm{Ca}^{2+}$ responses mediated by purinoceptors at perisynaptic Schwann cells. Soc Neurosci Abstr 20:707.

Robitaille R, Bourque MJ, Vandaele S (1995) Location of $\mathrm{Ca}^{2+}$ channels at perisynaptic glial cells in relation to the transmitter release sites. Can J Physiol Pharmacol 73:A22.

Salter MW, De Koninck Y, Henry JL (1993) Physiological roles for adenosine and ATP in synaptic transmission in the spinal dorsal horn. Prog Neurobiol 41:125-156.

Salter MW, Hicks JL (1994) ATP-evoked increases in intracellular calcium in neurons and glia from the dorsal spinal cord. J Neurosci 14: $1563-1575$.

Sanger Redman R, Silinsky EM (1993) A selective adenosine antagonist (8-cyclopentyl-1,3-dipropylxanthine) eliminates both neuromuscular depression and the action of exgenous adenosine by an effect on $A_{1}$ receptors. Mol Pharmacol 44:835-840.

Schwabe U, Lorenzen A, Grun S (1991) Adenosine receptors in the central nervous system. J Neural Transm 34:149-155.

Silinsky EM (1975) On the association between transmitter secretion and the release of adenine nucleotides from mammalian motor nerve terminals. I Physiol (Lond) 247:145-162.

Silinsky EM (1980) Evidence for specific adenosine receptors at cholinergic nerve endings. Br J Pharmacol 71:191-194.

Silinsky EM, Hunt JM, Solsona CS, Hirsh JK (1990) Prejunctional adenosine and ATP receptors. Ann NY Acad Sci 603:324-334.

Smith DO (1991) Sources of adenosine released during neuromuscular transmission in the rat. J Physiol (Lond) 432:343-354

Sneddon P, Burnstock G (1984) ATP as a co-transmitter in rat tail artery. Eur J Pharmacol 106:149-152.

Sneddon P, Westfall DP, Fedan JS (1982) Cotransmitters in the motor nerves of the guinea pig vas deferens: electrophysiological evidence. Science 218:693-695.

Stiles GL (1992) Adenosine receptors. J Biol Chem 267:645I-6454.

van Amsterdam FTM, Punt NC, Haas M, van Amsterdam-Magnoni MS, Zaagsma J (1989) Stereoisomers of BAY K 8644 show opposite activities in the normal and ischemic rat heart. Naunyn-Schmicdeberg's Arch Pharmacol 339:647-652.

Vizi ES, Sperlagh B, Lajtha A (1990) Evidence for a presynaptic $P_{2,-}$ purinoceptor involved in facilitation of acetylcholine release. Ann NY Acad Sci 603:500-502.

Voogd TE, Vansterkenburg ELM, Wilting J, Janssen LHM (199.3) Recent research on the biological activity of suramin. Pharmacol Rev 45:177-203.

Walz W, llschner S, Ohlemeyer C, Banati R, Kettenmann H (1993) Extracellular ATP activates cation conductance and a $\mathrm{K}^{\prime}$ conductance in cultured microglial cells from mouse brain. J Neurosci 13:44034411.

White TD (1988) Role of adenine compounds in autonomic neurotransmission. Pharmacol Ther 38:129-168.

Ziganshin AU, Hoyle CHV, Burnstock G (1994) Ecto-cnzymes and metabolism of extracellular ATP. Drug Dev Res 32:134-146.

Zimmermann H (1992) 5'-Nucleotidase: molecular structure and functional aspects. Biochem $\mathrm{J} 285: 345-365$.

Zimmermann H (1994) Signalling via ATP in the nervous system. Trends Neurosci 17:420-426. 